Table 1. Averages of Determinations in Triphicate With an 8 PER Cent DISPERSION ABOUT THE MEAN

\begin{tabular}{|c|c|c|c|c|c|c|c|}
\hline & & & & lution of & f serum & & $\begin{array}{c}T 2 \\
\text { phage }\end{array}$ \\
\hline tested & medium & $1 / 100$ & $1 / 500$ & $1 / 5,000$ & & $1 / 40,000$ & input \\
\hline Rabbit & Standard & 1 & 47 & 241 & 272 & 280 & 286 \\
\hline No. 1 & $\begin{array}{l}\text { Salt } \\
\text { deficient }\end{array}$ & 0 & 25 & 161 & 209 & 227 & 255 \\
\hline $\begin{array}{l}\text { Rabbit } \\
\text { anti- } \\
R 17\end{array}$ & $\begin{array}{l}\text { Standard } \\
\text { Salt- } \\
\text { deficient }\end{array}$ & $\begin{array}{l}301 \\
221\end{array}$ & $\begin{array}{l}286 \\
228\end{array}$ & $\begin{array}{l}321 \\
239\end{array}$ & $\begin{array}{l}321 \\
263\end{array}$ & $\stackrel{X}{X}$ & $\begin{array}{l}286 \\
255\end{array}$ \\
\hline $\begin{array}{l}\text { Rabbit } \\
\text { normal }\end{array}$ & $\begin{array}{l}\text { Standard } \\
\text { Salt- }\end{array}$ & $\begin{array}{l}300 \\
251\end{array}$ & $\begin{array}{l}296 \\
262\end{array}$ & $\begin{array}{l}282 \\
295\end{array}$ & $\begin{array}{l}320 \\
260\end{array}$ & $\begin{array}{l}290 \\
260\end{array}$ & $\begin{array}{l}286 \\
255\end{array}$ \\
\hline $\begin{array}{l}\text { Rabbit } \\
\text { anti-T2 }\end{array}$ & $\begin{array}{l}\text { Standard } \\
\text { Salt-deficient }\end{array}$ & $\begin{array}{c}1 / 10 \\
0 \\
0\end{array}$ & & $\begin{array}{l}, 000 \\
47 \\
48\end{array}$ & $\begin{array}{c}1 / 5,000 \\
177 \\
126\end{array}$ & $\begin{array}{l}10,000 \\
226 \\
159\end{array}$ & $\begin{array}{l}\text { phage } \\
\text { nput } \\
286 \\
255\end{array}$ \\
\hline
\end{tabular}

The number of plaques seen on the salt-deficient agar is 10.5 per cent of that noted on the standard medium.

which adsorption of the phage to the host cell occurred. The efficiency of plating was optimal when sodium ions were present at a concentration between 0.085 and 0.170 moles/l.

When $T 2$ phage is plated on the salt-deficient medium the number of plaques appearing is 10.5 per cent of the number noted if the same volume of $T 2$ phage suspension is plated on "standard" medium. The difference in efficiency of plating of phage $T 2$ on these two types of media may hold only for this phage, because there was no difference in the efficiency of plating of phage $T 7$ on either medium.

As shown in Table 1, inactivation of phage $T 2$ by specific antibody is observed when the phages are plated on "standard" medium. The number of plaques inactivated is increased when plating is performed on saltdeficient agar. The reason for this phenomenon is not clear. It is possible that the interaction of antibody and phage T2 may be stabilized in an environment with a low concentration of sodium ions. Hershey et al. ${ }^{2}$ observed that very dilute solutions of neutralizing antibody to phage $T 2$ could increase the efficiency of plating on saltdeficient media. At a serum dilution of $1 / 40,000$, this phenomenon was not observed on the media used in these experiments. The method deseribed in this communication may be of potential value in the assay of small amounts of neutralizing antibody to $T 2$ phage.

I thank Mrs. Hildegard Kuhl for able assistance.

Department of Chemistry,

Harvard University,

Cambridge 38, Massachusetts.

${ }^{1}$ Adams, M. H., Bacteriophages, 450 (Interscience, New York)

${ }^{2}$ Hershey, A. D., Kalmanson, G., and Bronfenbrenner, J., J. Immunol., 48, 221 (1944).

\section{Human Female Cycle of Urinary Oestrone}

THE patterns of urinary oestrone excretion during the human menstrual cycle which have been published $^{1-3}$ show two pronounced excretion peaks corresponding to ovulation and the luteal maximum which are between 8 and 11 days apart with a mean of 9 days. Despite the imprecision of the assay methods, a very small rise of urinary oestrone excretion could often be observed during menstruation with a peak 8-10 days before the ovulation peak. The development of our specific, more sensitive and precise method for determining urinary oestrone led us to the finding of an 8-10 day cycle of this urinary oestrogen in the normal human male, and to the suggestion that the periods of the urinary oestrone cycles in males and females are similar ${ }^{5}$. We therefore inferred that the normal human menstrual cycle is made up of three distinct urinary oestrone cycles with peaks of excretion between 8 and 11 days apart. The present communication gives the results of an investigation of the urinary oestrone excretion for the human menstrual cycle.

Urine was collected from a normal menstruating female of 25 years, weight $140 \mathrm{lb}$. and height $5 \mathrm{ft} .8 \mathrm{in}$., for 28 consecutive days-the length of this menstrual cycle. Activity and exercise during the period of urine collection were normal. Creatinine determinations were made by the method of Delory ${ }^{6}$ and the oestrone determinations by the method of Exley and Corker ${ }^{4}$. In order to detect the suspected small peak of urinary oestrone during the early days of the cycle most of the assays were carried out in triplicate or quadruplicate for the first 6 days.

The urinary oestrone results, which have been corrected for creatinine excretion, are shown in Table 1.

$\begin{array}{ccccc}\text { Table 1. URINARY OESTRONE THROUGHOUT THE HUMAN MENSTRUAL CYCLE } \\ \begin{array}{c}\text { No. of } \\ \text { Day of } \\ \text { cycle }\end{array} & \begin{array}{c}\text { Hetermina- } \\ \text { tions }\end{array} & \begin{array}{c}\text { Range } \\ (\mu \mathrm{g} / 24 \mathrm{~h})\end{array} & \begin{array}{c}\text { Cofficient* } \\ \text { of } \\ \text { variation }\end{array} & \begin{array}{c}\text { Mean } \\ \text { result } \\ (\mu \mathrm{g} / 24 \mathrm{~h})\end{array} \\ 1 & 2 & 1 \cdot 38-1 \cdot 52 & 5 \cdot 25 & 1 \cdot 45 \\ 2 & 3 & 1 \cdot 78-1 \cdot 93 & 4 \cdot 4 & 1 \cdot 85 \\ 3 & 3 & 2 \cdot 10-2 \cdot 26 & 3 \cdot 3 & 2 \cdot 18 \\ 4 \dagger & 4 & 3 \cdot 18-3 \cdot 42 & 3 \cdot 8 & 3 \cdot 30 \\ 5 & 2 & 2 \cdot 22-2 \cdot 42 & 4 \cdot 6 & 2 \cdot 32 \\ 6 & 4 & 3 \cdot 55-3 \cdot 80 & 3 \cdot 5 & 3 \cdot 68 \\ 7 & 1 & 5 \cdot 10-5 \cdot 40 & 2 \cdot 8 & 5 \cdot 25 \\ 8 & 1 & 9 \cdot 90-10 \cdot 10 & 0 \cdot 9 & 10 \cdot 00 \\ 10 & 1 & 14 \cdot 40-15 \cdot 20 & 2 \cdot 7 & 14 \cdot 80 \\ 12 & 1 & 16 \cdot 56-17 \cdot 30 & 2 \cdot 3 & 16 \cdot 95 \\ 14 \dagger & 1 & 17 \cdot 03-17 \cdot 40 & 1 \cdot 0 & 17 \cdot 20 \\ 16 & 1 & 9 \cdot 51-9 \cdot 69 & 0 \cdot 9 & 9 \cdot 60 \\ 18 & 1 & 7 \cdot 27-7 \cdot 53 & 1 \cdot 8 & 7 \cdot 40 \\ 20 & 1 & 8 \cdot 64-9 \cdot 04 & 2 \cdot 3 & 8 \cdot 84 \\ 22 & 1 & 10 \cdot 15-10 \cdot 25 & 0 \cdot 5 & 10 \cdot 20 \\ 24 & 1 & 15 \cdot 35-15 \cdot 85 & 1 \cdot 6 & 15 \cdot 60 \\ 26 & 1 & 5 \cdot 66-5 \cdot 94 & 2 \cdot 4 & 5 \cdot 80 \\ *\end{array}$

* Coefficient of variation, range and mean results of single determ
calculated from at least 3 or usually 4 or 5 specific activities (ref. 4 ).

+ Peaks of oestrone excretion.

The results clearly indicate the high order of accuracy and precision of the assay method. Except for days 12 and 14 , none of the ranges of a particular result overlaps those of the others. The results show that there are three peaks of urinary oestrono excretion with the peaks on days 4, 14 and 24 , and that this menstrual cycle if repeated could be subdivided into three phases of 8,10 and 10 days' duration.

The results of this investigation of the human menstrual cycle therefore confirm our previous predictions ${ }^{5}$ and add strength to the view that the hormone cycles of males and females may be controlled by similar types of neural regulation of hormonal interplay.

This work was supported in part by a grant from the U.S. National Institutes of Health (to M. C. L.).
D. EXLEY
MARJorie C. LINDBERG*
C. S. CORKER

Medical Research Council

Neuroendocrinology Research Unit,

Department of Human Anatomy,

University of Oxford.

* Permanent address: Department of Psychiatry, Stanford Medical Center, Palo Alto,California.

1 Pedersen-Bjergaard, G., and Pedersen-Bjergaard, K., Acta Endocrinol. Copenh., 1, 263 (1948)

Loraine, J. A., The Clinical Application of Hormone Assay, 175-177 (Livingstone, Edinburgh, 1958).

Brown. J. B., in The Endocrinology of Reproduction, 53, edit. by Lloyd, C. W. (Academic Press, New York, 1959).

4 Exley, D., and Corker, C. S., Biochem. J., 96, 818 (1965).

5 Exley, D., and Corker, C. S., J. Endocrinol., 35, 83 (1966).

- Delory, G. E., Photoelectric Methods in Clinical Biochemistry, 44 (Hilger and Watts, London, 1949).

\section{Accumulation of Anthoxanthins and Imino- acids in Leaf Galls of Salix fragilis L.}

GALL formation in the Salicaceae is common, and sawflies are frequently responsible. Investigation of the chemical changes initiated by the insects was made on the leaf galls of Salix fragilis L. produced by the sawfly Pontania proxima Lep. In preliminary studies, Challen ${ }^{1}$ suggested that one phytochemical change initiated by $P$. proxima might be an accumulation of catechins, leucoanthocyanidins and a ninhydrin positive substance. A red pigment, cyanidin-3-monoglucoside, was found in young leaves and galls by Blunden and Challen². In the present investigation a concentrated methanolic extract of fresh 